\title{
The challenges of post-bariatric surgery hypocalcaemia in pre-existing hypoparathyroidism
}

\author{
Annabel S Jones' ${ }^{1}$ Annabelle M Warren', Leon A Bach ${ }^{1,2}$ and Shoshana Sztal-Mazer1,2,3 \\ 1Department of Endocrinology and Diabetes, The Alfred Hospital, Melbourne, Australia, 2Department of Medicine \\ (Alfred), Monash University, Melbourne, Australia, and 'Womens' Health Research Program, School of Public Health \\ and Preventive Medicine, Monash University, Melbourne, Australia
}

Correspondence should be addressed to A S Jones

Email

annabel.jones7@gmail.com

\section{Summary}

Conventional treatment of hypoparathyroidism relies on oral calcium and calcitriol. Challenges in managing postparathyroid- and post-thyroidectomy hypocalcaemia in patients with a history of bariatric surgery and malabsorption have been described, but postoperative management of bariatric surgery in patients with established hypoparathyroidism has not. We report the case of a 46-year-old woman who underwent elective sleeve gastrectomy on a background of postsurgical hypoparathyroidism and hypothyroidism. Multiple gastric perforations necessitated an emergency Roux-en-Y gastric bypass. She was transferred to a tertiary ICU and remained nil orally for 4 days, whereupon her ionised calcium level was $0.78 \mathrm{mmol} / \mathrm{L}$ (1.11-1.28 mmol/L). Continuous intravenous calcium infusion was required. She remained nil orally for 6 months due to abdominal sepsis and the need for multiple debridements. Intravenous calcium gluconate $4.4 \mathrm{mmol} 8$ hourly was continued and intravenous calcitriol twice weekly was added. Euthyroidism was achieved with intravenous levothyroxine. Maintaining normocalcaemia was fraught with difficulties in a patient with pre-existing surgical hypoparathyroidism, where oral replacement was impossible. The challenges in managing hypoparathyroidism in the setting of impaired enteral absorption are discussed with analysis of the cost and availability of parenteral treatments.

\section{Learning points:}

- Management of hypoparathyroidism is complicated when gastrointestinal absorption is impaired.

- Careful consideration should be given before bariatric surgery in patients with pre-existing hypoparathyroidism, due to potential difficulty in managing hypocalcaemia, which is exacerbated when complications occur.

- While oral treatment of hypoparathyroidism is cheap and relatively simple, available parenteral options can carry significant cost and necessitate a more complicated dosing schedule.

- International guidelines for the management of hypoparathyroidism recommend the use of PTH analogues where large doses of calcium and calcitriol are required, including in gastrointestinal disorders with malabsorption.

- Approval of subcutaneous recombinant PTH for hypoparathyroidism in Australia will alter future management.

\section{Background}

Conventional treatment of hypoparathyroidism relies on gastrointestinal absorption of oral calcium and calcitriol. The management of hypocalcaemia in patients with a history of bariatric surgery or malabsorption is difficult. While the challenges in managing post-thyroidectomy hypocalcaemia in patients with a history of bariatric surgery has been described $(1,2)$, postoperative management of bariatric surgery in patients with established hypoparathyroidism has not. We present the case of marked and prolonged hypocalcaemia in a 46-year- 
old woman who underwent elective sleeve gastrectomy with multiple complications on a background of surgical hypoparathyroidism and hypothyroidism.

\section{Case presentation}

A 46-year-old woman decided to undergo elective sleeve gastrectomy. The patient weighed $95 \mathrm{~kg}$ with a BMI of $38.5 \mathrm{~kg} / \mathrm{m}^{2}$ at the time of surgery. Her past medical history included obesity, psoriatic arthritis treated with multiple immunosuppressants as well as surgical hypoparathyroidism and hypothyroidism following total thyroidectomy for a multinodular goitre 20 years previously. She had no history of diabetes, dyslipidaemia, hypertension or obstructive sleep apnoea. Her hypoparathyroidism was well managed on long term oral calcium carbonate and calcitriol . In November 2018 at a private metropolitan hospital, she had a planned sleeve gastrectomy, which was converted to emergency Roux-en-Y gastric bypass surgery due to multiple gastric perforations because of friable mucosa. Consequent abdominal sepsis required transfer to intensive care at a tertiary hospital 4 days post-operatively. Upon arrival, having remained nil orally, her calcium level was critically low at $0.78 \mathrm{mmol} / \mathrm{L}(1.11-1.28)$, though she was asymptomatic without seizure or arrhythmia (Table 1). A continuous intravenous calcium gluconate infusion was required to achieve normocalcaemia, followed by maintenance intermittent IV calcium boluses. The patient had a prolonged ICU admission of 6 months and required more than 20 abdominal operations. During this period, she received all medication and nutrition intravenously and lost $14 \mathrm{~kg}$. Endocrinology advice was required throughout her admission to manage her pre-existing hypoparathyroidism and hypothyroidism parenterally.

\section{Treatment}

Two weeks into her admission, Endocrinology advice was sought regarding the management of hypothyroidism;

Table 1 Ionised calcium results.

\begin{tabular}{lcc}
\hline & & lonised calcium, $\mathrm{mmol} / \mathrm{L}$ \\
\cline { 1 - 1 } $\begin{array}{l}\text { Reference Range } \\
\text { On admission to tertiary hospital }\end{array}$ & $\begin{array}{c}1.11-1.28 \\
(07 / 11 / 18)\end{array}$ & 0.78 \\
At the time of referral to & 1.04 \\
$\quad$ endocrinology $(25 / 11 / 18)$ & \\
At the time of discharge from & 1.23 \\
tertiary hospital $(30 / 5 / 19)$ & \\
\hline
\end{tabular}

her TSH was $5.83 \mathrm{mU} / \mathrm{L}$ (ref range $0.30-5.00 \mathrm{mU} / \mathrm{L}$ ) at this time. Intravenous triiodothyronine (T3) $10 \mu \mathrm{g}$ BD was commenced and euthyroidism was achieved after gradual up titration to $40 / 20 / 40 \mu \mathrm{g}$ daily based on TSH levels. On review, it was noted that high dose intravenous calcium, 4.4 mmol five times daily, was required through a central line to maintain normocalcaemia with ionised calcium being measured daily via routine blood gases. Serum phosphate level was 1.07 (ref range: $0.75-1.5 \mathrm{mmol} / \mathrm{K}$ ) and remained in the normal range throughout the hospital admission.

Intravenous calcitriol $1 \mu \mathrm{gg}$ alternate daily was, therefore, commenced 6 weeks into her admission, but was subsequently ceased 5 days later due to limited stock and high cost. Eight weeks into her admission, 150000 units of intramuscular cholecalciferol was trialled as it was readily available, but the low $1,25(\mathrm{OH})$ vitamin D3 level failed to increment, being $31 \mathrm{pmol} / \mathrm{L}$ (ref range 50-190) prior to administration and $29 \mathrm{pmol} / \mathrm{L} 3$ weeks after administration. Renal function was normal with eGFR $>90 \mathrm{~mL} / \mathrm{min} / 1.73 \mathrm{~m}^{2}$.

Three months into her admission, the patient still required intravenous calcium gluconate $4.4 \mathrm{mmol}$ five times daily to maintain normocalcaemia. Additional intravenous calcitriol was obtained and recommenced at a dose of $1 \mathrm{\mu g}$ alternate daily. This gradually reduced calcium gluconate requirements to $4.4 \mathrm{mmol}$ three times per day (Fig. 1). Of note, at this time, intramuscular thyroxine $600 \mu \mathrm{g}$ was trialled as a substitute for intravenous triiodothyronine, however, the patient found the injection painful. Therefore, intravenous thyroxine was commenced 4 days later at a dose of $200 \mu \mathrm{g}$ alternate daily. Eventually, a maintenance schedule that controlled both the hypocalcaemia and hypothyroidism was established (Table 2).

\section{Outcome and follow-up}

After a prolonged hospital stay of over 8 months, the patient recovered sufficiently to recommence oral intake. She was discharged on her preoperative calcitriol dose $(0.75$ $\mu \mathrm{g}$ daily) and an increased dose of calcium (1200 mg orally twice daily compared to $1200 \mathrm{mg}$ daily pre-operatively). She remained well replaced with normocalcaemia on review 6 weeks, 12 weeks and 4 months after discharge. At the time of her 4-month follow up, she weighed 71.8 $\mathrm{kg}$ and had a BMI of $29 \mathrm{~kg} / \mathrm{m}^{2}$.

\section{Discussion}

Calcium replacement may be difficult when enteral absorption is impaired. While oral treatment of 


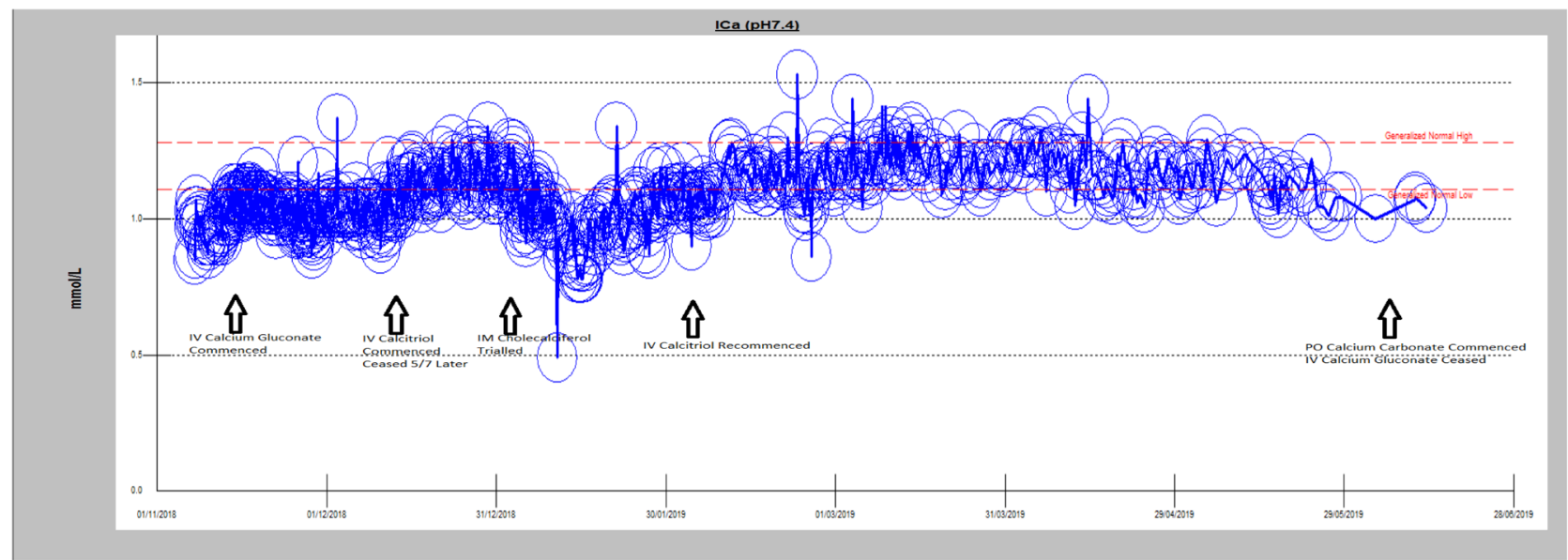

\begin{tabular}{|c|c|c|c|c|c|c|c|c|c|c|c|c|c|c|}
\hline \multicolumn{2}{|l|}{$\begin{array}{l}\text { Supplementation } \\
\text { administered }\end{array}$} & $\begin{array}{l}7- \\
21 / 11 / 1 \\
8\end{array}$ & $\begin{array}{l}21 / 11- \\
2 / 12 / 18\end{array}$ & $2-31 / 12 / 18$ & $\begin{array}{l}1- \\
14 / 1 / 19\end{array}$ & $\begin{array}{l}16- \\
25 / 1 / 19\end{array}$ & $\begin{array}{l}25 / 1- \\
13 / 2 / 19\end{array}$ & $\begin{array}{l}13- \\
20 / 2 / \\
19\end{array}$ & $\begin{array}{l}20- \\
24 / 2 / \\
19\end{array}$ & $\begin{array}{l}24 / 2- \\
15 / 3 / 19\end{array}$ & $15 / 3-27 / 5 / 19$ & $\begin{array}{l}27- \\
29 / 5 / 19\end{array}$ & $29 / 5-28 / 8 / 19$ & $\begin{array}{l}28 / 8- \\
30 / 11 / 19\end{array}$ \\
\hline \multirow[t]{2}{*}{$\begin{array}{l}\text { Calcium dose } \\
\mathrm{mmol} / \mathrm{lor} \mathrm{mg}\end{array}$} & IV & $\begin{array}{l}\text { Continu } \\
\text { ous }\end{array}$ & $\begin{array}{l}4.4 \mathrm{x} \\
5 / \mathrm{d}\end{array}$ & $4.4 \times 4 / d$ & $\begin{array}{l}4.4 x \\
4 / d\end{array}$ & $4.4 \times 6 / \mathrm{d}$ & $\begin{array}{l}4.4 x \\
5 / d\end{array}$ & $\begin{array}{l}4.4 x \\
4 / d\end{array}$ & $\begin{array}{l}4.4 \mathrm{x} \\
3 / \mathrm{d}\end{array}$ & $\begin{array}{l}4.4 x \\
4 / d\end{array}$ & $4.4 \times 3 / d$ & & & \\
\hline & 0 & & & & & & & & & & & $1200 / d$ & $1200 \times 2 / d$ & $1200 \times 2 / d$ \\
\hline \multirow[t]{2}{*}{ Calcitriol dose $\mathrm{mcg}$} & IV & & & $\begin{array}{l}1 \times 3 \text { doses } \\
\text { alt/daily }\end{array}$ & & & & $\begin{array}{l}1 \text { alt } \\
\text { daily }\end{array}$ & $\begin{array}{l}1 \text { alt } \\
\text { daily }\end{array}$ & $\begin{array}{l}1 \text { alt } \\
\text { daily }\end{array}$ & 1 alt daily & & & \\
\hline & 0 & & & & & & & & & & & $0.75 / \mathrm{d}$ & $0.75 / \mathrm{d}$ & $0.75 / \mathrm{d}$ \\
\hline $\begin{array}{l}\text { Cholecalciferol } \\
\text { IU }\end{array}$ & & & & & $\begin{array}{l}150000 \\
\times 1 \text { dose }\end{array}$ & & & & & & & & & \\
\hline
\end{tabular}

Figure 1

Ionised calcium levels with associated parenteral treatment for hypoparathyroidism during admission.

hypoparathyroidism with calcium carbonate and calcitriol is cheap and relatively simple, available parenteral options can carry significant costs, require central line access and necessitate a more complicated dosing schedule (Table 3).

Our patient was managed with intravenous calcium gluconate, and subsequently, intravenous calcitriol was added. As may have been expected, parenteral cholecalciferol did not alter the 1,25(OH)vitamin D level due to absent endogenous PTH, which is required to activate cholecalciferol.

We explored the costs of possible alternative treatment options for non-oral management of hypoparathyroidism (Table 2). The PTH analogue PTH 1-34 (teriparatide) is used for osteoporosis. Some studies have demonstrated the benefit of subcutaneous PTH 1-34 in maintaining normocalcaemia in patients with hypoparathyroidism (3). Continuous PTH 1-34 treatment almost eliminated diurnal variations in calcium levels and improved hypercalcaemia in two studies comparing pump and injection therapy in adults and children $(4,5)$.
Similarly, continuous PTH (1-34) treatment via a pump improved calcium homeostasis in three patients with uncontrolled hypocalcaemia post-operatively despite receiving subcutaneous PTH 1-34 treatment (6). Unlike with PTH 1-84, which is discussed below, there are no clinical trials for registration on teriparatide treatment in hypoparathyroid patients, however, a prospective openlabel study in post-surgical patients with fixed twice daily dosing demonstrated a significant reduction in calcium requirements and improved quality of life (7).

The full recombinant human PTH molecule, PTH 1-84 (NatPara) has been shown to be effective and well tolerated with improved quality of life vs standard therapy $(8,9)$ A US randomised controlled trial addressing the safety and efficacy of daily PTH (1-84) demonstrated that $53 \%$ of patients receiving PTH (1-84) achieved the primary end point of a $\geq 50 \%$ reduction in their baseline dose of oral calcium and vitamin D while maintaining normal serum calcium levels, compared to $2 \%$ in the placebo group (8). International guidelines

Table 2 Comparison between oral and intravenous doses required for maintenance treatment of hypoparathyroidism and hypothyroidism.

\begin{tabular}{ll}
\hline & Pre-existing oral treatment \\
\hline Calcium carbonate & $1200 \mathrm{mg}$ daily \\
Calcitriol & $0.75 \mu \mathrm{g}$ daily \\
Levothyroxine & $200 \mu \mathrm{g}$ daily \\
\hline
\end{tabular}

\begin{tabular}{l} 
Maintenance i.v. treatment \\
\hline Calcium gluconate 4.4 mmol three times per day \\
$1 \mu$ g every 2 days \\
$200 \mu$ g every 3 days
\end{tabular}


Table 3 Parenteral options for the treatment of hypoparathyroidism.

Treatment option and dose
IV Calcitriol
IV Calcium gluconate
Teriparatide (PTH 1-34)
NatPara (PTH-1-84)

\begin{tabular}{l} 
Dosing schedule \\
\hline $1 \mu g$ IV every 4 days \\
$0.25 \mu g$ IV daily \\
4.4 mmol IV $5 x$ daily \\
4.4 mmol IV $3 x$ daily \\
$20 \mu g$ subcut twice daily \\
$50-100 \mu g$ subcut daily
\end{tabular}

\begin{tabular}{l}
\hline Cost per month (approx.) AUD \\
$\$ 120$ \\
$\$ 480$ \\
$\$ 1674$ \\
$\$ 1004$ \\
$\$ 824$ \\
$\$ 11995$ (via Special Access Scheme)
\end{tabular}

\begin{tabular}{l} 
Availability in Australia \\
\hline Available \\
Available \\
Off-label Indication \\
Special access scheme only \\
(FDA approved 2015)
\end{tabular}

for the management of hypoparathyroidism (2016), therefore, recommend the use of PTH 1-84, where large doses of calcium and calcitriol are required, including in gastrointestinal disorders with malabsorption (10). However, this practice has not become standard in our institution as its use is not government subsidised because it has not yet been included in the Australian Register of Therapeutic Goods.

Other groups have reported how they improved enteral absorption of calcium and calcitriol in patients with surgical hypoparathyroidism where parathyroidectomy occurred after bariatric surgery. Their approaches included escalating oral doses, gastrostomy tube insertion and pancreatic enzyme supplementation $(11,12)$. None would have been appropriate in our case because of abdominal sepsis and friable mucosa. Ours represents the first case in the literature, to our knowledge, whereby gastric bypass surgery was undertaken in an individual with pre-existing hypoparathyroidism.

We propose careful consideration be given before elective bariatric surgery in patients with pre-existing hypoparathyroidism due to potential difficulties in managing hypocalcaemia in the setting of impaired gastrointestinal absorption, which is exacerbated when complications occur. Approval of subcutaneous recombinant PTH for hypoparathyroidism in Australia will alter future management.

\section{Declaration of interest}

The authors declare that there is no conflict of interest that could be perceived as prejudicing the impartiality of the research reported.

\section{Funding}

This research did not receive any specific grant from any funding agency in the public, commercial or not-for-profit sector

\section{Author contribution statement}

All authors were involved in the clinical care of the patient and contributed to the writing of this manuscript.

\section{References}

1 McKenzie TJ, Chen Y, Hodin RA, Shikora SA, Hutter MM, Gaz RD, Moore FD \& Lubitz CC. Recalcitrant hypocalcemia after thyroidectomy in patients with previous Roux-en-Y gastric bypass. Surgery 2013154 1300-1303; discussion 1306. (https://doi. org/10.1016/j.surg.2013.04.031)

2 Royer P. Hormonal regulation of calcium metabolism: biology and pathology. In Pediatric Endocrinology, chapter 6, 2nd ed., pp. 477-543. Eds J-C Job \& M Pierson. New York: John Wiley \& Sons, 1991.

2 Chereau N, Vuillermet C, Tilly C, Buffet C, Trésallet C, du Montcel ST \& Menegaux F. Hypocalcemia after thyroidectomy in patients with a history of bariatric surgery. Surgery for Obesity and Related Diseases 201713 484-490. (https://doi.org/10.1016/j.soard.2016.09.026)

3 Winer KK, Ko CW, Reynolds JC, Dowdy K, Keil M, Peterson D, Gerber LH, McGarvey C \& Cutler GB. Long-term treatment of hypoparathyroidism: a randomized controlled study comparing parathyroid hormone-(1-34) versus calcitriol and calcium. Journal of Clinical Endocrinology and Metabolism 200388 4214-4220. (https:// doi.org/10.1210/jc.2002-021736)

4 Winer KK, Zhang B, Shrader JA, Peterson D, Smith M, Albert PS \& Cutler GB. Synthetic human parathyroid hormone 1-34 replacement therapy: a randomized crossover trial comparing pump versus injections in the treatment of chronic hypoparathyroidism. Journal of Clinical Endocrinology and Metabolism 201297 391-399. (https://doi. org/10.1210/jc.2011-1908)

5 Winer KK, Fulton KA, Albert PS \& Cutler Jr GB. Effects of pump versus twice-daily injection delivery of synthetic parathyroid hormone 1-34 in children with severe congenital hypoparathyroidism. Jurnalul Pediatrului 2014165 556.e1-563.e1. (https://doi.org/10.1016/j.jpeds.2014.04.060)

6 Fuss CT, Burger-Stritt S, Horn S, Koschker A-C, Frey K, Meyer A $\&$ Hahner S. Continuous rhPTH (1-34) treatment in chronic hypoparathyroidism. Endocrinology, Diabetes and Metabolism Case Reports 2020 200009. (https://doi.org/10.1530/EDM-20-00092020)

7 Santonati A, Palermo A, Maddaloni E, Bosco D, Spada A, Grimaldi F, Raggiunti B, Volpe R, Manfrini S, Vescini F, et al. PTH(1-34) for surgical hypoparathyroidism: a prospective, open-label investigation of efficacy and quality of life. Journal of Clinical Endocrinology and Metabolism 2015 $1003590-3597$. (https://doi.org/10.1210/jc.2015-1855)

8 Mannstadt M, Clarke BL, Vokes T, Brandi ML, Ranganath L, Fraser WD, Lakatos P, Bajnok L, Garceau R, Mosekilde L, et al. Efficacy and safety of recombinant human parathyroid hormone (1-84) in hypoparathyroidism (REPLACE): a double-blind, placebo-controlled, randomised, phase 3 study. Lancet: Diabetes and Endocrinology 20131 275-283. (https://doi.org/10.1016/S2213-8587(13)70106-2)

9 Cusano NE, Rubin MR, McMahon DJ, Irani D, Anderson L, Levy E \& Bilezikian JP. PTH (1-84) is associated with improved quality of life in hypoparathyroidism through 5 years of therapy. Journal of Clinical Endocrinology and Metabolism 201499 3694-3699. (https://doi. org/10.1210/jc.2014-2267)

10 Brandi ML, Bilezikian JP, Shoback D, Bouillon R, Clarke BL, Thakker RV, Khan AA \& Potts JT. Management of 
hypoparathyroidism: summary statement and guidelines. Journal of Clinical Endocrinology and Metabolism 2016101 2273-2283. (https:// doi.org/10.1210/jc.2015-3907)

11 Hayes D, Tan L, Feczko A \& Sniezek J. Recalcitrant hypocalcemia in Roux-en-Y gastric bypass patients after parathyroidectomy: successful management with gastrostomy tube placement. Archives of otorhinolaryngology. Head and Neck Surgery 20182 5. (https://doi. org/10.24983/scitemed.aohns.2018.00086)

12 Panazzolo DG, Braga TG, Bergamim A, Pires B, Almeida H \& KraemerAguiar LG. Hypoparathyroidism after Roux-en-Y gastric bypass - a challenge for clinical management: a case report. Journal of Medical Case Reports 20148 357. (https://doi.org/10.1186/1752-1947-8-357)

Received in final form 23 August 2020

Accepted 10 September 2020 